\title{
$\mathbf{R}$

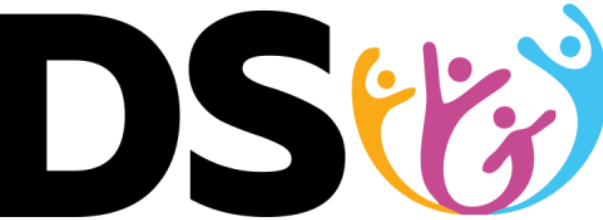

Vol. 26, n. 2, jul/dez, 2020

Revista Desenvolvimento Social

ISSN: 2179-6807 (online)

\section{ORIGEM E CONSTITUIÇÃO HISTÓRICA DAS DEVOÇÕES SANTEIRAS EM MINAS GERAIS}

João Valdir Alves de Souza ${ }^{1}$

Recebido em: $12 / 11 / 2020$

Aprovado em: 22/12/2020

Resumo: É entendimento corrente o fato de a sociedade brasileira ser predominantemente católica. Esse catolicismo, contudo, é historicamente marcado por dois subsistemas que disputam espaços de poder e influência: um institucional, centrado nos sacramentos e na mediação do clero, e outro popular, de corte devocional, centrado no culto aos santos. Essas devoções santeiras resultaram basicamente da ação dos próprios colonizadores que vieram para - Brasil trazendo sua fé, seus santos e respectivas crenças, festas, promessas e penitências. Longe do catolicismo institucional e dos regulamentos do Vaticano, essas práticas religiosas diversificaram-se ainda mais quando se fundiram com elementos religiosos de indígenas e africanos. Em Minas Gerais, onde as ordens religiosas foram proibidas de se instalar ao longo do século XVIII, foram criadas ordens terceiras, irmandades e associações religiosas de toda espécie. Isso fez com que frutificasse um catolicismo leigo ou catolicismo popular que coube ao Vaticano tentar enquadrar, sobretudo a partir do final do século XIX, naquilo que ficou conhecido como "romanização do catolicismo".

Palavras-chave: Devoções santeiras; catolicismo popular; festas religiosas; Minas Gerais; romanização do catolicismo.

\section{GENESIS AND HISTORICAL CONSTITUTION OF SAINT DEVOTIONS IN MINAS GERAIS}

\begin{abstract}
It is common understanding that Brazilian society is predominantly Catholic. This Catholicism, however, is historically marked by two subsystems that dispute spaces of power and influence: an institutional, centered in the sacraments and in the mediation from the clergy; and other popular, devotional, centered on the cult of saints. These saint devotions resulted from the action of the colonizers who came to Brazil bringing their faith, beliefs, saints of devotion, religious celebrations, penances and promises. Far from institutional Catholicism and Vatican regulations, these religious practices were already varied depending on the colonizers origins and became even more diversified when it merged with religious elements of Indians and Africans. In Minas Gerais, the religious orders were forbidden to be installed throughout the eighteenth century, as a consequence of this prohibition people created third orders, fraternities and religious associations of all kinds. Thereat, in Minas Gerais, more than any other Brazilian state, fructified a Catholic lay or popular Catholicism that Vatican tried to frame,
\end{abstract}

\footnotetext{
${ }^{1}$ Professor Titular de Sociologia da Educação da Faculdade de Educação da Universidade Federal de Minas Gerais (UFMG); https://orcid.org/0000-0002-4201-8060; jvaldir@ufmg.br
} 
especially from the late nineteenth century, a process that became known as "Romanization of Catholicism."

Keywords: Saint devotions; popular Catholicism; religious celebrations; Minas Gerais; Romanization of Catholicism.

\section{ORIGEN Y CONSTITUCIÓN HISTÓRICA DE LAS DEVOCIONES SANTEIRAS EN MINAS GERAIS}

Resumen: Es un entendimiento común que la sociedad brasileña es predominantemente católica. Este catolicismo, sin embargo, está históricamente marcado por dos subsistemas que disputan espacios de poder e influencia: uno institucional, centrado en los sacramentos y en la mediación del clero, y otro popular, de corte devocional, centrado en el culto a los santos. Esas devociones santeiras resultaron de la acción de los propios colonizadores que vinieron a Brasil trayendo su fe, sus santos y sus respectivas creencias, fiestas, penitencias y promesas. Lejos del catolicismo institucional y las regulaciones del Vaticano, estas prácticas religiosas se volvieron aún más diversas cuando se fusionaron con elementos religiosos de los pueblos indígenas y africanos. En Minas Gerais, donde se prohibió el asentamiento de órdenes religiosas a lo largo del siglo XVIII, se crearon órdenes terceras, hermandades y asociaciones religiosas de todo tipo. Esto llevó a la realización de un catolicismo laico o catolicismo popular que fue responsabilidad del Vaticano tratar de encuadrar, especialmente desde finales del siglo XIX, lo que se conoció como la "romanización del catolicismo".

Palabras-clave: Devociones santeiras; catolicismo popular; fiestas religiosas; Minas Gerais; romanización del catolicismo.

\section{INTRODUÇÃO}

O estudioso das manifestações religiosas no Brasil se vê hoje diante de uma enorme variedade delas e de muitas maneiras diferentes de abordá-las. Mesmo quando se trata de interpretar o conjunto de crenças e de práticas que atendem pelo nome "catolicismo" essa realidade não é diferente. Conforme afirma Carlos Alberto Steil, a partir do final do século XIX, esse catolicismo passa a se organizar em dois subsistemas "que vão disputar espaços de poder e de influência na sociedade brasileira: um popular, de corte devocional, centrado no culto aos santos, e outro moderno, centrado nos sacramentos e na mediação do clero." (STEIL, 2001, p. 16).

Para começarmos a entender como se constituem historicamente esses dois subsistemas, talvez seja necessário voltar, ainda que rapidamente, às origens da implantação do catolicismo em terras brasileiras, acompanhar sua trajetória e explicitar porque o Brasil é um país predominantemente católico. Mais do que compreender como se constituem esses subsistemas, realizar esse movimento nos permite 
compreender também alguns dos modos de "ser católico" no Brasil atual, analisar em que medida esses modos dialogam entre si ou entram em conflito e retirar dessa análise os elementos necessários ao que aqui nos interessa: compreender as origens e como se constituem historicamente as devoções santeiras em Minas Gerais. Neste ano em que se comemoram os 300 anos de criação do estado (02/12/1720 - 02/12/2020), trazer à luz alguns dos elementos da sua formação sociocultural certamente nos permitirá ampliar o conhecimento sobre a mineiridade.

\section{CATOLICISMO NO BRASIL}

Parece ser tão óbvio o entendimento do que ela é, uma vez que é vista como uma instituição "conatural" à sociedade brasileira, que poucos se dão conta de que é necessário perguntar: o que é a Igreja? E o que é a Igreja católica? Como, aqui, parte-se do pressuposto de que o óbvio precisa ser explicitado, a primeira tarefa a que este texto se propõe é, senão definir, pelo menos trazer alguns elementos para o claro entendimento dos principais conceitos empregados a seguir.

Em termos bem genéricos, pode-se dizer que Igreja é a entidade moral que agrega o conjunto dos fiéis que partilham um mesmo corpo de crenças e práticas religiosas dentro do cristianismo. Católico vem do grego katholikós, que quer dizer universal, ou seja, é a reivindicação do monopólio do sagrado pela afirmação de que Cristo é o único e verdadeiro filho de Deus, portador da única mensagem salvífica no contexto do monoteísmo. Grafada com $i$ minúsculo, igreja é o mesmo que templo, lugar sagrado destinado ao culto divino e realização dos rituais dos fiéis. O templo dos judeus é a sinagoga; o dos muçulmanos é a mesquita; o dos praticantes de candomblé é o terreiro. Grafada com I maiúsculo, Igreja é a entidade moral que agrega os diversos conjuntos de fiéis cristãos.

Desde já fica claro, portanto, o quanto é difícil definir o catolicismo, uma vez que ele é ao mesmo tempo a pretensão abstrata da universalidade e a expressão concreta das fraturas históricas que fragmentaram a Igreja universal em milhares de igrejas cristãs, sendo a própria Igreja católica muito diversificada internamente. Enquanto as igrejas que se filiam ao protestantismo se subdividem em grupos autônomos e em denominações diferentes, o catolicismo tende a absorver a diversidade no seu próprio 
interior, contrapondo com uma eficiente elasticidade à lógica da divisão que caracteriza as igrejas protestantes. (STEIL, 2001, p. 33). Para o que aqui nos interessa, vamos tomar a Igreja católica como o conjunto de crenças, práticas, regulamentos e instituições que se organizam em conformidade com as ordenações do Vaticano e devem obediência ao Papa como sua autoridade máxima, independentemente de essa obediência se verificar na sua totalidade.

A Igreja católica apostólica romana, "sacramento hierárquico" de realização da "universal unidade", nas palavras de Pierre Sanchis (SANCHIS, 1992, p. 13), se organiza em torno de uma enorme quantidade de igrejas particulares, as dioceses, que por sua vez agrupam diferenciado número de paróquias. A diocese, que é o mesmo que bispado, é uma circunscrição territorial submetida à administração eclesiástica de um bispo que a administra em cooperação com o presbitério, isto é, os padres, sacerdotes ou mediadores sacramentais da Instituição. Um conjunto de dioceses forma uma província eclesiástica com sede metropolitana na arquidiocese, que é uma circunscrição eclesiástica entregue à administração de um arcebispo. No Brasil, até 1899, havia 17 dioceses e 2 arquidioceses. Em 1996, eram 251 dioceses e 35 arquidioceses. Esses números expressam claramente a expansão do aparato burocrático-institucional da Igreja católica em terras brasileiras ao longo do século XX.

O fato de o Brasil ser um país predominantemente católico resulta de uma longa e complexa história, impossível de ser resumida em poucos parágrafos. Vamos ter em mente, entretanto, que os colonizadores portugueses eram profundamente católicos e que já na famosa viagem de Pedro Álvares Cabral um frade franciscano que acompanhava a expedição, Henrique Soares de Coimbra, celebrou missa tão logo os marinheiros puseram os pés em terra. Pouco tempo depois, com a vinda do primeiro governador-geral, Tomé de Sousa, em 1549, seis padres jesuítas, chefiados por Manuel da Nóbrega, vieram com o propósito de realizar a catequese e cuidar da educação. A forte presença dos jesuítas no Brasil colônia deve ser entendida como uma estratégia da Igreja católica para avançar em direção ao Novo Mundo, num momento em que o catolicismo europeu era sacudido pela reforma protestante.

Até o final do século XIX, a Igreja católica foi praticamente única no trabalho de "salvação das almas", isto é, ela tentou levar adiante a pretensão da universalidade, reivindicando para si o monopólio do sagrado. Esse trabalho não se deu sem conflitos, 
como demonstra vasta bibliografia. (cf. SOUZA, 2000). As coordenadas culturais dos europeus eram radicalmente diferentes das dos nativos, algo em torno de 5 milhões de indivíduos espalhados por imenso território, e das dos africanos, trazidos em massa em função do trabalho escravo. Para entender o catolicismo que se formou em terras brasileiras, torna-se necessário analisar as formas específicas como foram se fundindo elementos da cultura religiosa dos colonizadores, dos nativos e dos africanos e os sucessivos sincretismos que daí resultaram. Pierre Sanchis coordenou vasta pesquisa, publicada em três volumes, que traça um ótimo retrato dessa diversidade. (SANCHIS, 1992). Posteriormente, o próprio Sanchis organizou livro que trata especificamente do sincretismo (SANCHIS, 2001).

Dessa fusão resultou uma cultura religiosa híbrida, mas com forte preponderância dos elementos católicos. Essa preponderância decorreu de três frentes principais de atuação dos europeus, caracterizada por Eduardo Hoornaert, autor de vasta obra sobre história do catolicismo na América Latina, como "catolicismo guerreiro". (HOORNAERT, 1991; 1992; 1994; cf., também, AZZI, 1978; 1987). Uma delas foi a do próprio Vaticano que, em sua íntima relação com o governo português, garantiu prerrogativas exclusivas de atuação da Igreja na colônia. Não havia liberdade de culto antes de 1824, ela era limitada no período imperial e, somente a partir da República, que separou a Igreja do Estado, outras confissões religiosas passaram a ter o direito de atuar livremente. Apesar de sua ação nesses primeiros séculos ser ainda bastante limitada, o Vaticano estabelecia que cada nova diocese deveria criar um seminário, como meio de formar um corpo eclesiástico voltado para a difusão da religião católica. Em Minas, as duas primeiras dioceses - e seus respectivos seminários - são as de Mariana, criada em 1745, e Diamantina, criada em 1854 (ainda que instalada apenas dez anos depois).

Uma segunda frente foi a dos religiosos das ordens, principalmente franciscanos e jesuítas. Esses religiosos tiveram atuação destacada, sobretudo no litoral e nos cursos dos grandes rios, acompanhando as frentes de ocupação do território brasileiro. Ao trabalho missionário e catequético somou-se a primeira experiência de escolarização formal que o Brasil conheceu. Em todos os casos tratava-se de converter os indígenas à fé católica e ensinar os rudimentos da escrita aos filhos de colonos, além de instruí-los no catolicismo. Entre a data de sua chegada ao Brasil, em 1549, e o ano em que foram 
expulsos pelo Marquês de Pombal, 1759, os jesuítas fundaram 15 colégios, quase todos em cidades históricas do litoral.

Uma terceira frente foi a dos próprios colonizadores que vieram para o Brasil trazendo sua fé, suas crenças, seus santos de devoção, suas festas religiosas e sua confiança nas penitências e no pagamento de promessas. Longe do catolicismo institucional e dos regulamentos do Vaticano essas práticas religiosas, que já eram diversificadas em função das origens dos colonizadores, se diversificaram ainda mais quando se fundiram com elementos religiosos de indígenas e africanos. Em Minas Gerais, por exemplo, onde as ordens religiosas foram proibidas de se instalar ao longo do século XVIII, foram criadas ordens terceiras, irmandades e associações religiosas de toda espécie. Isso fez com que em Minas, mais do que em qualquer outro estado brasileiro, frutificasse um catolicismo leigo ou catolicismo popular que coube ao Vaticano tentar enquadrar, sobretudo a partir do final do século XIX, naquilo que ficou conhecido como "romanização do catolicismo".

"Romanizar" o catolicismo significava submeter as práticas religiosas dos fiéis aos regulamentos de Roma. Em Minas Gerais a romanização começou com uma "reforma da Igreja" (AZZI, 1978, p. 68), para a qual muito contribuíram os bispos das duas únicas dioceses existentes no estado até o final do século XIX, Dom Antônio Ferreira Viçoso, no governo da diocese de Mariana entre 1844 e 1875, e Dom João Antônio dos Santos, em Diamantina, entre 1864 e 1905. Essa reforma consistia em formar novos seminaristas no espírito de união com Roma, com demonstração de fidelidade ao papa, à fé católica e submissão aos ordenamentos da hierarquia eclesiástica, em síntese, visava a disciplinar o clero. ${ }^{2}$

20 clero é composto de sacerdotes diocesanos ou seculares e de sacerdotes religiosos ou regulares. Aqueles (diocesanos ou seculares) são formados nos seminários diocesanos e, quando admitidos na diocese, devem obediência ao bispo, como chefe da igreja particular e representante do papa na administração da Igreja local. Estes (religiosos ou regulares) são membros de uma ordem ou congregação religiosa e devem obediência ao superior de cada ordem. Segundo consta no Dicionário Enciclopédico das Religiões, as ordens religiosas são "associações de indivíduos da mesma crença que decidem viver num ambiente diverso da sociedade dos homens comuns, para se libertarem dos interesses e preocupações mundanos e levarem uma vida de sacrifício e ascetismo. (...) O caráter típico das ordens religiosas cristãs é a regulamentação rígida de toda a atividade de seus membros, que chega, em muitos casos, a exigir a abnegação completa do indivíduo. A ordenação religiosa distingue-se, por conseguinte, do mero sacerdócio, por um rigor mais acentuado. Os membros de cada ordem fazem voto de pobreza, castidade e obediência. Cada ordem tem sua regra interna, exigindo maiores ou menores sacrifícios de seus membros." Dentre as principais ordens e/ou congregações religiosas criadas a partir do século $X$, destacam-se: carmelitas (1207), franciscanos (1209), dominicanos (1215), mercedários (1218), servitas de 
Além disso, o aparato burocrático-institucional foi significativamente ampliado, com a criação de dioceses e paróquias em todo o território nacional. No estado de Minas Gerais, entre 1900 e 1929, foram criadas 11 das 28 dioceses aí existentes até 1996. E, ainda: intensificou-se o trabalho missionário e catequético; foram criadas irmandades e associações religiosas sintonizadas com o espírito renovador; as lideranças leigas dos centros de romaria e das irmandades tradicionais foram substituídas pelo pároco, agora instituído como líder espiritual; e, principalmente, desde 1820, quando o colégio do Caraça foi entregue aos lazaristas portugueses, abriu-se à entrada de uma enorme quantidade de ordens e congregações religiosas, masculinas e femininas, que passaram a assumir destacado papel na assistência à saúde (Santas Casas de Misericórdia) e na educação escolar. ${ }^{3}$

Foi em decorrência desse longo percurso que se constituíram os dois subsistemas aos quais se referiu Carlos Alberto Steil, citado anteriormente. A constituição de um subsistema católico institucional, centrado nos sacramentos e na mediação do clero, e de outro, popular, de corte devocional, centrado no culto aos santos é um dos resultados visíveis do processo de romanização do catolicismo, que atravessou, não sem conflito, a história da Igreja católica no Brasil e na América Latina ao longo dos séculos XIX e XX. Aqui nos interessa particularmente esse segundo subsistema, porque ele é que dá sustentação às devoções santeiras.

\section{AS DEVOÇÕES SANTEIRAS}

A devoção é um estado de espírito ao qual se associam determinadas práticas dos fiéis, que expressam o sentimento e o reconhecimento de uma dependência fundamental da criatura em relação a um criador. Presente em todas as grandes

\footnotetext{
Maria (1233), agostinianos (1256), jesuítas (1534), lazaristas ou padres da missão (1625), lassalistas (1680), redentoristas (1732), assuncionistas (1845). O Dicionário Enciclopédico das Religiões identifica 60 ordens e 245 congregações religiosas, masculinas e femininas, diferentes. (cf. PORTO e SCHLESINGER, 1995 , p. 665-682 e 1934-1944).

3Entre 1890 e 1921, entraram $10(47,6 \%)$ das 21 congregações religiosas masculinas que se instalaram em Minas entre meados do século XVI e o ano de 1992. No mesmo período, instalaram-se 20 (50\%) das 40 congregações femininas. A maioria absoluta delas, tanto masculinas quanto femininas, era composta de congregações fundadas na segunda metade do século XIX. Entre 1890 e 1961, foram fundados 30 dos 31 colégios religiosos masculinos que se estabeleceram em Minas nos séculos XIX e XX. No mesmo período, foram fundados 72 dos 77 colégios religiosos femininos. (LOPES e BICALHO, 1993).
} 
religiões, a devoção se manifesta pela entrega da vida pessoal a uma entidade externa à qual se credita o poder de realizar aquilo que está além das possibilidades humanas. As devoções santeiras são expressões da piedade popular, uma manifestação de fé nos santos da Igreja católica. Elas se exprimem nas festas dos padroeiros, nas procissões, nas penitências e peregrinações, vistas pelos fiéis como forma de mobilizar um poder mais alto que aquele que reconhecem no plano da vida em sociedade.

De onde vêm essas devoções santeiras? Segundo o Dicionário Enciclopédico das Religiões, a palavra "santo" deriva do hebraico kadosh, que significa separado. (PORTO e SCHLESINGER, 1995, p. 2296). Santas são pessoas que, por uma manifestação de poder milagroso, extraordinário ou sobrenatural apresentaram a capacidade de ser excepcionalmente diferentes das demais; ou coisas destinadas ao cultivo do sagrado, que também expressa algo que é separado daquilo que é da vida comum, e, por isso mesmo, é constituído objeto de culto e reverência; santos também são os dias reservados ao serviço religioso, à purificação do corpo e do espírito e à separação entre o que deve e o que não deve ser cultuado em nome da divindade.

Parece ser possível, no entanto, dizer que as devoções santeiras são uma remanescência do politeísmo, um sistema de crenças que consiste na adoração a vários deuses, cada qual associado a um elemento distinto da vida humana e da existência do mundo natural. Rompendo com esse sistema de crenças, a Igreja cristã primitiva herdou do judaísmo a doutrina do Deus único, isto é, o monoteísmo, que não só criou uma entidade única à qual se credita a origem e o desígnio de todas as coisas, como distanciou-a dos mortais comuns. Deus tornou-se uma entidade demasiadamente poderosa e distante, inatingível, senão através de algumas mediações. Os santos se transformaram em mediadores privilegiados nessa relação entre os homens e a divindade, herdando do politeísmo uma especificidade no exercício da mediação, como a proteção a determinadas categorias de trabalhadores, a proteção de certas partes do corpo ou a cura de algumas afecções corporais ou, ainda, a ligação a certas causas específicas. ${ }^{4}$

4Existem, por exemplo, os santos protetores de determinadas categorias de trabalhadores (São José é o santo dos carpinteiros; Santa Quitéria é santa dos mineradores; Santo Isidoro é o santo dos lavradores; São Cristóvão é o santo dos motoristas etc). Existem os santos protetores de certas partes do corpo ou certas afeç̧ões corporais (Santa Luzia é protetora dos olhos; São Brás Bispo, protetor da garganta; Santa Apolônia, protetora dos dentes. São Sebastião é invocado para estancar hemorragia, ou conter a peste, a 
Para os cristãos, o mediador principal é o próprio Cristo. Quando seus seguidores começaram a elaborar seu corpo de doutrina, isto é, sua teologia, eles passaram a dar nome às várias modalidades de ação de Deus no mundo. Atribuiu-se a Deus Pai a criação do homem e de todas as coisas que existem. À sua manifestação mais direta no mundo atribuíram a vinda de Cristo, o Deus Filho, enviado para realizar a aproximação entre o criador e sua criatura. À mais alta esfera de poder, isto é, ao princípio ativo de Deus operando no mundo, elo entre Pai e Filho, e, por extensão, à ligação da esfera da divindade e a esfera dos homens, chamaram Espírito Santo. Assim, o cristianismo elaborou uma complexa concepção teológica, na figura de um único Deus que é três ao mesmo tempo. Torna-se necessário um elaboradíssimo exercício de abstração para entender o mistério da Trindade, isto é, como é possível ser Deus único, que é, ao mesmo tempo, Pai, Filho e Espírito Santo, e, ainda, imagem e semelhança do próprio homem criado, como todo catecismo pretende fazer crer.

Segundo a literatura bíblica, o Espírito Santo se manifestou aos apóstolos, através de línguas de fogo, cinquenta dias após a Páscoa e sete dias após a ascensão de Cristo. ${ }^{5}$ A partir daí, o Pentecostes, que era a "Festa da Colheita" judaica, passou a ser o sinal da existência do Espírito que Jesus prometera enviar aos apóstolos após sua partida. Com isso, os apóstolos assumiram a tarefa de difundir a mensagem de Cristo, tornando-se, pois, os primeiros cristãos e mediadores entre os homens e Deus nessa nova concepção religiosa. O Espírito Santo passou a ser venerado como o santo supremo, a própria expressão de uma das pessoas da Trindade. Com o tempo, as pessoas às quais foi atribuída a capacidade de realizar atos que estão acima das capacidades humanas passaram a ser vistas como portadores de uma aura de santidade.

\footnotetext{
fome ou a guerra; São João, para aliviar dor de garganta e dor de cabeça; São Cláudio, para aliviar os furúnculos; Santa Petronilha, para fazer baixar a febre; São Lázaro, para dar combate às feridas crônicas ou malignas; São Roque, para proteger das mordidas de cachorros). Existem, ainda, os santos que advogam causas específicas (Santa Rita, para advogar as causas impossíveis; São Bento, para espantar cobras e outros animais peçonhentos; São Francisco de Assis, para achar animal fugido; Santa Clara, para limpar o mau tempo; Santa Bárbara e São Jerônimo, para acalmar tempestades; São Judas Tadeu, para aliviar grandes aflições ou desesperos; Santa Edwiges, para socorrer os devedores; Santo Antônio, para proteger os namorados).

5 Segundo a doutrina cristã, Deus filho desceu à terra, encarnou em Cristo e novamente subiu ao céu. "A ascensão ao Céu constitui a etapa final da peregrinação terrena de Cristo." (...) "Liturgicamente é celebrada na Igreja católica no domingo que antecede o Pentecostes." (PORTO e SCHLESINGER, 1995, p. 2296).
} 
Essas pessoas passaram a compor a enorme galeria de santos cultuados e festejados mundo afora pelos devotos.

Mas a quem cabia reconhecer essa santidade nessas pessoas excepcionais? Para a Igreja-instituição essa era tarefa para seu corpo de profissionais especializados, os únicos capazes de regular e estabelecer o monopólio do sagrado e, portanto, de reconhecimento da santidade. Para a Igreja-povo de Deus bastava o reconhecimento da legitimidade da manifestação do carisma ou da graça divina. Desde os primórdios, portanto, enquanto a Igreja-instituição canoniza alguns santos e os reconhece e difunde como modelos de virtude e exemplo a ser seguido, a Igreja-povo estabelece e venera seus próprios santos, os "pequenos santos", em função de suas necessidades pessoais ou sociais. (OLIVEIRA e ARAÚJO, 2011). E isso nem sempre expressa consenso entre as duas partes.

\section{ORIGENS DO ESTADO DE MINAS E DE SUAS DEVOÇÕES SANTEIRAS}

Como se sabe, a despeito da importância que a atividade agropecuária teve na formação histórica de Minas Gerais, sobretudo aquela derivada do desbravamento do rio São Francisco, a historiografia mineira ainda hoje é marcada pela abordagem da mineração e seus desdobramentos, destacando-se a centralidade que Vila Rica e adjacências tiveram nesse processo. Mesmo sendo consensual o entendimento de que Minas são muitas, está também subjacente a esse consenso o entendimento de que há uma "Minas geratriz", como dizia Guimarães Rosa, e que essa gênese está localizada na região onde predominou a atividade mineradora. É inevitável, portanto, dar-lhe algum destaque.

Se se pode atribuir a Minas Gerais uma certidão de nascimento, certamente ela é o alvará que D. João V expediu a 02 de dezembro de 1720, criando a Capitania Independente de Minas Gerais, destacando-a da antiga capitania de São Paulo e Minas, que havia sido criada em $1709 .{ }^{6}$ Apesar de o dito alvará argumentar apenas que todas as informações que se tomaram de várias pessoas concordam uniformemente "em ser muito conveniente a meu serviço e bom governo das ditas capitanias de São Paulo e

6Até o início do século XIX, delimitava-se a "capitania". No Império, a "província". A denominação "estado" é uma criação da República. 
Minas e à sua defensa que as de São Paulo se separem das que pertencem às Minas" (VEIGA, 1998, p. 1025) é de se supor que a divisão em duas e a destinação de governos diferentes a elas se devem, por um lado, à relevância que a atividade mineradora adquiria na colônia e, por outro, ao risco que o governo corria de perder o controle da situação em decorrência das diversas revoltas ocorridas, a exemplo da de Felício dos Santos, no mesmo ano de 1720.

Por essa ocasião já havia pelo menos duas décadas que o ouro das Minas dos Matos Gerais tinha constituído na região o eldorado que atraíra para seu entorno enorme contingente populacional. Segundo João Antônio de Paula, em Raízes da Modernidade em Minas Gerais, sem dúvida uma das melhores sínteses da história de Minas, apesar de ter havido, durante todo o período colonial, apenas um núcleo urbano que recebeu o título de cidade, Mariana, "foi Minas Gerais, durante todos os séculos XVIII e XIX, a região mais urbanizada e populosa do Brasil." (PAULA, 2000, p. 34). Mais que isso, diz o autor, os índices de urbanização e a dinâmica demográfica de Minas Gerais são mais elevados que o padrão urbano-demográfico do Novo Mundo e mesmo que os prevalecentes na Europa. Esse processo de ocupação do território tem uma longa e complexa história, não cabendo aqui mais que uma indicação de seus contornos e implicações gerais.

Vila Rica de Albuquerque foi criada em 08 de julho de 1711, a segunda da região das minas. A primeira, criada em 08 de abril, foi a vizinha Vila de Nossa Senhora do Carmo de Albuquerque (atual Mariana), que foi também a primeira capital, a primeira cidade e a primeira diocese; e a terceira foi a Vila Real de Nossa Senhora da Conceição de Sabará, todas três datadas daquele mesmo ano de 1711. Depois vieram São João Del Rei, em 1713; Vila Nova da Rainha (Caeté) e Vila do Príncipe, em 1714; Vila Nova do Infante (Pitangui), em 1715; Vila de São José Del Rei (Tiradentes), em 1718; Vila de Nossa Senhora do Bom Sucesso das Minas do Fanado (Minas Novas), em 1730, para citar apenas as primeiras. Até o final do século XIX criava-se a vila, a qual era dotada do aparato burocrático-administrativo, fiscalizador e punitivo do Estado. Posteriormente, mais como expressão de prestígio que como jurisdição administrativa, ela poderia ser elevada à condição de cidade. As "cidades históricas" mineiras são uma construção da historiografia para designar o conjunto de cidades que foram edificadas no contexto da mineração (cf. COSTA, 1997; BARBOSA, 1995). 
Essa centralidade conferida à região mineradora pela historiografia, contudo, não nos pode fazer esquecer a importância das atividades agropecuárias na formação sociocultural e econômica de Minas Gerais, o que confere a esse estado enorme diversidade. Na realidade, a rota da mineração avançou a partir do sul da capitania, antes mesmo da sua criação, e se instalou na região central (Ouro Preto, Mariana, São João del-Rei, Sabará, Caeté), avançou pela Serra do Espinhaço até o alto Jequitinhonha (Serro, Diamantina, Itacambira, Minas Novas e Grão Mogol) e demarcou um único ponto a noroeste da capitania (Paracatu), prosseguindo até as minas de Goiás e Mato Grosso. Tudo isso nas três primeiras décadas do século XVIII, numa avalanche de descobertas de ouro de aluvião, de nascimentos de povoados e criação de vilas, de deslocamentos inéditos de população nas terras de além-mar.

Enquanto isso, num ritmo bem mais lento, mas não menos significativo, outra rota de ocupação do território já havia alcançado o que veio a ser a porção norte da capitania de Minas Gerais: a rota do São Francisco, o "rio dos currais", para usar expressão já consagrada. Se a primeira foi caracterizada pelo ritmo frenético da atividade mineradora e pela força do elemento urbano no ordenamento da vida social, esta segunda acompanhava o ritmo próprio do passo de boi e fundou as bases de uma organização social, ainda hoje, fortemente marcada pelos elementos constitutivos do mundo rural. Encontrando-se as duas rotas, na região central da capitania, nos primórdios do século XVIII, elas não apenas permitiram a ligação entre o sul e o norte da colônia pelo interior - o que fez do São Francisco o rio da "integração nacional" mas também constituíram o eixo central a partir do qual, desde então e por três séculos seguintes, essa ocupação avançasse para o oeste (Triângulo Mineiro, início do século $\mathrm{XIX),} \mathrm{para} \mathrm{o} \mathrm{nordeste} \mathrm{(Vale} \mathrm{do} \mathrm{Jequitinhonha} \mathrm{e} \mathrm{do} \mathrm{Mucuri,} \mathrm{ao} \mathrm{longo} \mathrm{do} \mathrm{século} \mathrm{XIX)} \mathrm{e} \mathrm{para}$ vastas porções das antigas "áreas proibidas dos sertões do leste" (início e meados do século $X X$ ), num movimento que atingiu a última fronteira dos sertões de Guimarães Rosa, no noroeste do estado, já no terceiro quartel do século XX (SOUZA e HENRIQUES, 2010).

Bem dizia Guimarães Rosa que “Minas Gerais é muitas. São, pelo menos, várias minas" (apud PAULA, 2000, p. 15). Há uma grande diversidade no seu quadro natural, caracterizado por matas fechadas e campos limpos, íngremes montanhas e planícies abertas, sertões a perder a vista. Pelo menos três grandes biomas compõem a paisagem: 
Mata Atlântica, Cerrado e Caatinga e as múltiplas variações em suas interfaces. Basta lembrar que essas "áreas proibidas dos sertões do leste", eram extensão de Mata Atlântica em território mineiro, e constituíram, até meados do século XIX, uma barreira natural ao contrabando, garantindo de certa forma o controle do tráfego das riquezas da terra pela única via autorizada, a "Estrada Real". O cerrado e suas variações ocupam todo o centro-oeste do estado e a caatinga é prolongamento do semiárido nordestino em território mineiro.

Há uma grande diversidade econômica e produtiva expressa nas minas de ouro e diamantes, na extração mineral e, mesmo desde o início do século XVIII, na agricultura, na pecuária e na manufatura. Posteriormente, a agricultura e a pecuária se desdobram na manufatura agrícola, a manufatura urbana se desdobra na grande indústria, campo e cidade passam a compor o complexo agroindustrial. É uma relação tensa, contraditória e conflituosa é verdade, mas tudo isso se constitui ao lado de amplas áreas de agricultura familiar e de rica e diversificada produção artesanal. Mais que diversificada, essa economia expressa uma brutal desigualdade, posto que se caracterizou historicamente por ser concentradora da renda e da riqueza, marginalizadora e excludente.

E há, ainda, uma grande diversidade sociocultural, marcada por uma relação conflituosa e até mesmo violenta, produto da fusão de matrizes culturais indígenas, africanas e europeias. Diferentemente do mundo rural do norte, essa urbanidade predominante no sul permitiu desde o início a constituição de um grande mercado consumidor, a formação de uma classe média urbana, o desenvolvimento artístico e cultural do barroco e do rococó, a presença de uma burocracia administrativa, a criação de entidades agregadoras da sociedade civil, a diversificação de categorias ocupacionais, a ampliação da mobilidade social. Além disso, como resultado de um processo de três séculos de formação, há uma enorme variedade de formas de expressão cultural que atende pelo complexo termo "cultura popular", cuja principal esfera de manifestação é a das festas para os santos da devoção da quase totalidade dessa população.

Esse "popular", que remete tanto à cultura em geral quanto a uma forma específica de sua manifestação, a religiosidade, tem sido objeto de enorme quantidade de estudos ao longo do tempo. (GONZÁLEZ, 1992; VALLA, 2001; SOUZA, 2009). Entender 
o que é a cultura popular e, por extensão, o catolicismo popular, não é tarefa das mais simples. Segundo o historiador francês Roger Chartier (1995), a cultura popular é, na realidade, uma categoria erudita. Ele quis dizer com isso que a expressão "cultura popular", e, mais que isso, o conceito de "cultura popular" não foram elaborados pelo povo a quem ela se refere. As pessoas do povo não se referem a si mesmas como pertencentes à cultura popular ou à religiosidade popular. Ela é uma categoria erudita porque foi uma elaboração realizada na academia, por pesquisadores ávidos por criar classificações e tipologias. A fim de caracterizar um tipo de manifestação própria de determinados grupos sociais e diferenciá-la de outros tipos é que os vocábulos foram ganhando forma e adquirindo significados diferentes ao longo do tempo.

Esses significados diferentes ao longo do tempo ganharam forma de acordo com os processos sociais que combinaram elementos macro e micro em particularidades históricas. Daí a necessidade, de novamente, voltarmos a alguns desses elementos que resultaram nas particularidades históricas que nos permitem ler em Minas sua especificidade face a outras regiões do país. E se há um traço forte nessa cultura é o que tem sido sistematicamente identificado como catolicismo leigo ou catolicismo popular.

Desde o início da colonização ordens religiosas, irmandades leigas e pregadores independentes estiveram a serviço da difusão do catolicismo em terras brasileiras, e em Minas Gerais isso se deu de modo peculiar. O trabalho das ordens ligou-se, principalmente, à conversão das diversas populações indígenas espalhadas por todo o território colonial. Proibidas na capitania de Minas Gerais entre 1709 e 1820, justamente no período mais frutífero da atividade mineradora, as ordens religiosas continuaram a sua atuação nas proximidades do litoral ou dos grandes cursos d'água, como na região Amazônica, no vale do São Francisco e na bacia do rio da Prata. (RUBERT, 1988; HOORNAERT, 1992; BOSCHI, 1986; PAULA, 2000; SOUZA, 2000).

Foi principalmente nos lugares onde as ordens religiosas não atuaram que floresceram e se frutificaram ordens terceiras, irmandades leigas e pregadores populares. Se as ordens foram proibidas na região das minas, as irmandades, pelo contrário, não apenas foram permitidas como estimuladas, dando origem a entidades de forte conotação sexista, classista e étnica. Distante da atenção dos religiosos e excluídos das irmandades dos brancos, os negros criaram seus próprios mecanismos de 
proteção edificando, além das igrejas, as irmandades dos santos da sua devoção, como São Benedito, Santa Efigênia e, principalmente, Nossa Senhora do Rosário.

Estudando as associações religiosas da região mineradora de Minas Gerais, Fritz Teixeira de Salles, afirma que a sua função social foi completamente diferente daquelas que se estabeleceram no litoral. Enquanto nas outras regiões a propagação religiosa era uma tarefa realizada pelas grandes ordens religiosas, como os jesuítas e os franciscanos, em Minas "não as existindo, a Coroa tratou de estimular as irmandades, a fim de - com elas e através delas - transferir ao próprio povo, isto é, aos mineradores, comerciantes e escravos, os encargos tão dispendiosos de construir os grandes templos, os cemitérios, etc." (SALLES, 1963, p. 27). Isso foi de interesse tanto da Coroa quanto da Igreja, porque Ihes poupava do investimento nas grandiosas obras que foram o marco dessa cultura religiosa e nos complexos e caros cerimoniais dos seus cultos. Essa transferência de responsabilidades para as associações religiosas durou até o momento em que Igreja e Estado se viram ameaçados pelo seu poder, momento a partir do qual começaram a lhes impor limites ao crescimento e à influência.

Mas o que eram essas associações religiosas e qual o seu papel como mediadoras na difusão do catolicismo? Segundo Fritz Teixeira de Salles, o Código do Direito Canônico identifica três classes de associações religiosas, a saber: as Confrarias, as Pias Uniões (Irmandades) e as Ordens Terceiras Seculares. As mais simples ou elementares, as Pias Uniões, são associações de fiéis que tenham sido constituídas para exercer alguma obra de piedade ou caridade. Se forem constituídas como organismos regulados por um compromisso passam a se chamar irmandades. E se essas irmandades tiverem sido erigidas com o objetivo de incrementar o culto público, elas recebem o nome particular de confrarias. "As confrarias só podem ser eretas por decreto formal de ereção; enquanto às pias uniões basta aprovação do Ordinário". (SALLES, 1963, p. 16).

Humberto Porto e Hugo Schlesinger, no entanto, definem as confrarias simplesmente como "associações para fins religiosos ou caritativos." Essas associações, dizem eles, existem desde o começo do cristianismo, mas somente na Idade Média tiveram maior desenvolvimento. Muitas delas foram constituídas sem o consentimento da Igreja, outras, fugindo às suas finalidades originais, "tenderam para o gnosticismo e mesmo para o ateísmo", fazendo-se secretas e, com o tempo, dando origem a várias correntes francomaçônicas. Essas associações estão na base das devoções santeiras, 
uma vez que mesmo que se propusessem à realização de artes e ofícios, à assistência aos enfermos ou à promoção de enterros de mortos indigentes, "sua função principal era promover a devoção a um santo. Havia dois tipos de confraria: a irmandade e a ordem terceira." (PORTO e SCHLESINGER, 1995, p. 654).

A irmandade é uma associação de caráter religioso, cuja identidade é definida por um compromisso ou estatuto, a marca da sua constituição como um "organismo". Sua presença, no Brasil, é forte desde o início da colonização, podendo-se distinguir dois tipos básicos: as que se destinam à assistência social e as que se dedicam às atividades devocionais. Até o século XIX, as irmandades de Misericórdia, que deram origem às atuais Santas Casas, eram as únicas entidades de caráter filantrópico. As irmandades de caráter devocional também prestavam assistência, mas exclusivamente aos confrades e suas famílias. Sua principal atividade era o culto ao santo patrono, destacando-se a Irmandade do Santíssimo Sacramento, dos brancos; a de Nossa Senhora do Amparo, de pardos; e a de Nossa Senhora do Rosário, de negros. (OLIVEIRA, 1976, p.133; PORTO e SCHLESINGER, 1995, p. 1403).

Raro foi o núcleo urbano brasileiro que não contou com uma Irmandade do Santíssimo desde a sua fundação. Ela sempre foi a responsável pela igreja matriz, uma antiga prescrição do padroado, ainda que existissem outras irmandades de brancos. E a principal característica de praticamente todos os centros urbanos brasileiros é o fato de terem se formado ao redor de uma igreja, principalmente católica. Fritz Teixeira de Salles chega a afirmar que, no início do povoamento, elas eram obrigatórias, uma vez que simbolizavam a "autoridade suprema da corte celeste e que arregimentavam as pessoas de maior projeção do arraial". (SALLES, 1963, p. 20). Ricas ou pobres, mas sempre influentes, as irmandades do Santíssimo foram se constituindo, ao longo do tempo, como uma das principais referências do culto religioso, desde os maiores centros urbanos do litoral até os minúsculos lugarejos no interior do país.

A ordem terceira é uma associação piedosa e devocional de fiéis que tem por principal finalidade aprimorar a vida cristã de seus membros. Ela é inspirada nas regras de uma ordem religiosa que, por sua vez, é uma associação caracterizada pela aceitação de uma vida regida pelos votos de obediência, castidade e pobreza, como já foi dito. Livrando-se do ambiente da sociedade dos homens, pretendem os membros das ordens religiosas alcançar a graça da salvação da alma em virtude de uma vida de abnegação e 
sacrifícios. De modo geral, as ordens se inspiram em concepções de vida gestadas na antiguidade cristã, segundo as quais o homem pode chegar à perfeição moral e espiritual através da disciplina e da mortificação do corpo.

Fundamentando-se nesse princípio ascético, as ordens religiosas foram se formando, principalmente a partir do século X. (PORTO e SCHLESINGER, 1995; FISCHERWOLLPERT, 1997; CECHINATO, 1996). Inicialmente, apareceram algumas comunidades autônomas, sob a direção de um superior. Depois foram se constituindo, num contexto de grande diversidade organizacional e de objetivos, aquelas ordens que se tornariam as grandes responsáveis pela difusão do catolicismo mundo afora.

Já a partir do século XI, dizem Porto e Schlesinger, duas correntes se destacam: a ascética, que pregava o isolamento do mundo (como os beneditinos) e a que enfatizava a necessidade da ação no mundo (como os trinitários, da Ordem Hospitalar da Santíssima Trindade). Por essa época é que foram criadas as ordens mendicantes, que não estavam sujeitas às obrigações paroquiais; as ordens militares, que se integraram ao movimento das cruzadas; e as ordens terceiras, cujos membros, embora tentassem seguir os princípios ascéticos, não faziam votos e nem se desligavam da vida mundana. Essas ordens terceiras são associações que se vinculam às ordens religiosas, sobretudo naquilo que diz respeito à veneração particular e ao culto público do santo, mas seus membros não se afastam da vida secular. Três são as principais confrarias às quais se ligam as ordens terceiras: os franciscanos, os dominicanos e os carmelitas. (cf., também, PALAZZOLO, 1973; KOPPEN, 1989; KOPPEN, s. d.; PEREIRA, 1998).

Naquele que talvez seja o melhor e mais completo estudo sobre a origem das irmandades leigas e ordens terceiras em Minas Gerais, Os Leigos e o Poder, Caio César Boschi afirma que se houve proibição da entrada e fixação de ordens religiosas na região das minas o que explica a presença de numeroso clero e de majestosos templos é a constituição de irmandades leigas, "responsáveis pela contratação de religiosos para a prática dos ofícios sacros, bem como pela construção dos templos mineiros do século XVIII". (BOSCHI, 1986, p. 2). No conjunto, foram, portanto, essas associações religiosas as responsáveis pela entrada e cultivo do devocionário que marca a história cultural da região das minas. Segundo ainda Caio César Boschi, é "difícil determinar com exatidão a data em que foram criadas as primeiras irmandades no território mineiro". No entanto, continua ele, "se se parte do pressuposto de que era à sombra do templo que os fiéis se 
congregavam, certamente será no estudo das primeiras capelas ali construídas que se encontrará a resposta." (BOSCHI, 1986, p. 21).

Nesse caso, parece não haver dúvida de que elas começaram a aparecer com os primeiros moradores que aí se fixaram, uma vez que em cada povoado era construído um templo ou mesmo uma simples capela. De qualquer forma, antes mesmo da criação das primeiras vilas, em 1711, "a presença e a atuação delas já eram incontestáveis." (BOSCHI, 1986, p. 23). Nessa época, Sabará já tinha pelo menos três irmandades (Santa Quitéria, Santo Antônio do Bom Retiro e Santíssimo Sacramento), São João del Rei tinha duas (Nossa Senhora do Rosário e Santíssimo Sacramento) e Mariana e Vila Rica tinham a de Nossa Senhora do Rosário dos Pretos.

Digno de nota é a presença de Irmandades de Nossa Senhora do Rosário desde os primórdios da ocupação do território. Digno de nota, também, é o fato de quase $20 \%$ do total de 322 irmandades identificadas por Boschi, isto é, 62, serem de invocação a Nossa Senhora do Rosário, enquanto o segundo lugar fica com Irmandades do Santíssimo, com 43 invocações, ou 13\% do total. (BOSCHI, 1986, p. 187). Ainda segundo Caio César Boschi, embora a invocação e o culto dos santos tenham sido incentivados pelo Concílio de Trento, "eles correspondiam a reivindicações essencialmente imediatistas e temporais, retratando o caráter intimista e familiar do culto." Interpretando Eduardo Hoornaert, para quem os santos poderiam ser considerados "símbolos da variedade racial e social do Brasil", ele afirma que Nossa Senhora do Rosário, São Benedito, São Elesbão, Santa Efigênia e, mais tarde, Nossa Senhora das Mercês, eram invocações dos negros não apenas pela afinidade epidérmica ou pela identidade de origem geográfica, mas pela identidade com suas agruras e seu desejo de redenção. (BOSCHI, 1986, p. 25).

Apaziguamento das agruras e busca da redenção, independentemente da vinculação racial e social, caracterizam dois traços fundamentais desse catolicismo popular: sua dimensão sacrificial e seu aspecto celebrativo. A dimensão sacrifical remete a uma "relação contratual" estabelecida entre fiel e seu santo de devoção, por meio da qual "um sistema de trocas de bens simbólicos" (STEIL, 2001, p. 22) obriga o fiel ao pagamento da promessa em retribuição à graça alcançada, de modo que a penitência tende a ser tão mais severa quanto mais difícil julga-se ser a causa. Muitos são os lugares, no Brasil, que se constituíram como centros de romaria, a exemplo de 
Aparecida (SP), Juazeiro do Norte (CE), Bom Jesus da Lapa (BA). Em Minas, esses centros de romaria podem ser identificados em várias regiões, a exemplo de Romaria (Triângulo Mineiro), Congonhas e Conceição do Mato Dentro (Central) e Virgem da Lapa (Vale do Jequitinhonha). Rubem César Fernandes descreve de modo bem humorado o acompanhamento a um desses rituais de pagamento de promessa (FERNANDES, 1994), mas nossa literatura é rica em exemplares que exploram a questão, como o Auto da compadecida, de Ariano Suassuna, e $\mathbf{O}$ pagador de promessas, de Dias Gomes.

Quanto ao aspecto celebrativo, destacam-se as festas para todos os santos e santos para todas as causas, em todas as grandes, médias e pequenas localidades que conseguirmos identificar, muitos deles trazendo no nome do lugar a referência ao santo ou à santa de devoção. Mesmo com a reforma toponímica realizada em Minas Gerais, em 1923, sob influência da República, é notável o número de localidades cujo nome expressa a força da influência religiosa católica na formação sociocultural do estado. Desde a dimensão material, que pode ser estudada pela economia da cultura, até a dimensão simbólica, que tem sido objeto de grande variedade de estudos em todas as áreas das ciências humanas, as festas religiosas celebram a existência e expressam a exaltação coletiva dos sentimentos de liberdade das amarras da vida cotidiana. Caracterizadas pelo desregramento e pela subversão desse ordenamento ordinário da vida cotidiana, as festas se situam em oposição à lógica do cálculo que preside o mundo do trabalho, tornando-se efervescência, exaltação dos sentidos, compartilhamento de sentimentos e emoções levados ao paroxismo. Além disso, a festa é um ritual, anualmente repetida em datas comemorativas, consagrando-se o princípio religioso da religere, isto é, da re-ligação, do revigoramento, da reciprocidade, da reafirmação dos elos que unem o grupo social.

\section{CONCLUSÃO}

Por ocasião da comemoração dos seus 300 anos, tentei apontar alguns dos elementos constitutivos da formação sociocultural do estado de Minas Gerais. Dada a amplitude das possiblidades de abordagem, o texto se limita a indicar alguns dos marcos da origem do estado, destacando que, a despeito do peso que a atividade mineradora teve nesse processo e da centralidade que a historiografia mineira ainda confere à 
mineração, a história do estado não se limita às cidades históricas. Pelo contrário, bem vistas as coisas, a atividade mineradora que deu visibilidade a Minas no cenário colonial e, posteriormente, nacional não ocupava mais que $20 \%$ do território. Além disso, a ocupação desse território se deu ao longo de três séculos e qualquer análise que se queira fazer atualmente do nosso cenário precisa considerar os modos peculiares como essa expansão se deu e o tipo particular de atividade econômica que se estabeleceu em cada local.

Ao abordar a formação sociocultural, destaquei a dimensão da religiosidade de matriz católica, tentando explicar por que ela tem sido caracterizada como "leiga" e "popular", isto é, como ela se formou quase que totalmente à revelia da ação institucional da Igreja católica. Tentei explicar, também, a origem das devoções santeiras, traço forte dessa religiosidade popular. A partir da segunda metade do século XIX é que a instituição começa a agir com seu corpo de profissionais, na tentativa de submeter as práticas religiosas dos fiéis aos ordenamentos de Roma. A esse procedimento dá-se o nome de "romanização do catolicismo". A despeito de todo o aparato burocrático-institucional montado com esse propósito, em Minas e no Brasil persiste ainda hoje aquilo que Carlos Alberto Steil (2001) identificou como dois subsistemas católicos disputando "espaços de poder e de influência na sociedade brasileira: um popular, de corte devocional, centrado no culto aos santos, e outro moderno, centrado nos sacramentos e na mediação do clero."

Essas devoções santeiras constituíram-se ao mesmo tempo em que a população se fixava no território e expressam a variada cultura religiosa que aí se estabeleceu, uma vez que elas se fundiram com outras referências culturais, principalmente de africanos, a exemplo da Festa do Rosário e das congadas. Vêm daí os embates que, ainda hoje, podem ser verificados na tentativa do Vaticano em regulamentar práticas religiosas. Enquanto o trabalho do clero é doutrinar, dentro de um contexto de presença institucional cada vez mais forte, a devoção não necessariamente se assenta em instituições especializadas, difundindo-se junto à população pela própria dinâmica cultural. Isso é relevante tanto para as localidades onde existiram associações quanto para aquelas onde o aparato institucional da Igreja ou era frágil ou muito distanciado da população. Na amplitude do diversificado estado de Minas Gerais, além do trabalho das ordens terceiras e irmandades religiosas, atuaram pregadores leigos, ermitães, 
benzedores e rezadores populares. Atuaram os próprios devotos, defendendo suas crenças, construindo suas igrejas e celebrando seus santos de devoção.

Nesse cenário de abertura de fronteiras, de conquista do espaço, de domínio do mundo físico e de organização da vida social é que se formou a diversificada religiosidade nas minas gerais e se consolidaram as devoções santeiras e as respectivas festas de santo como uma das suas principais expressões culturais. Mesmo com todo o trabalho levado a efeito, em nome da romanização, salta aos olhos o fato de que as práticas culturais são algo de bem mais difícil controle institucional do que geralmente se supõe.

\section{REFERÊNCIAS}

AZZI, Riolando. “O início da restauração católica em Minas Gerais: 1920-1930". Síntese, v. 5, n. 14, set-dez. 1978, p. 65-91.

. A cristandade colonial: um projeto autoritário. São Paulo: Paulinas, 1987.

BARBOSA, Waldemar de Almeida. Dicionário Histórico-Geográfico de Minas Gerais. Belo Horizonte: Editora Itatiaia, 1995.

BOSCHI, Caio César. Os leigos e o poder: irmandades leigas e política colonizadora em Minas Gerais. São Paulo: Ática, 1986.

CECHINATO, Luiz. Os vinte séculos de caminhada da lgreja: principais acontecimentos da cristandade, desde os tempos de Jesus até João Paulo II. Petrópolis: Vozes, 1996.

CHARTIER, Roger. Cultura popular: revisitando um conceito historiográfico. Estudos históricos, Rio de Janeiro, vol. 8, n. 16, 1995.

COSTA, Joaquim Ribeiro. Toponímia de Minas Gerais. Belo Horizonte: BDMG Cultural, 1997.

FERNANDES, Rubem César. Romarias da paixão. Rio de Janeiro: Rocco, 1994.

FISCHER-WOLLPERT, Rudolf. Os papas: de Pedro a João Paulo II. $3^{\mathrm{a}}$ ed. Petrópolis: Vozes, 1997.

GONZÁLEZ, José Luís; BRANDÃO, Carlos Rodrigues; IRARRÁZAVEL, Diego. Catolicismo popular: história, cultura, teologia. Petrópolis: Vozes, 1992.

HOORNAERT, Eduardo. Formação do catolicismo brasileiro - 1550-1800. $3^{\mathrm{a}}$ ed. Petrópolis: Vozes, 1991.

. História da Igreja no Brasil: ensaio de interpretação a partir do povo. Tomo II/2. Segunda época: A Igreja no Brasil no século XIX. $3^{\text {a }}$ ed. São Paulo: Edições Paulinas, 1992.

História do cristianismo na América Latina e no Caribe. São Paulo: Paulus, 1994.

KOPPEN, Frei Helano van. OFM. Nossas paróquias mineiras nos últimos 25 anos do Comissariado Franciscano de Santa Cruz (1925-1950). Juiz de Fora: s. e., 1989. 
Rumo à província brasileira: os últimos vinte e cinco anos do comissariado franciscano de Santa Cruz (1925-1950). Suas casas de formação e ensino. Belo Horizonte: Editora O Lutador, s.d.

LOPES, Eliane Marta S. Teixeira e BICALHO, Marly Gonçalves. "Colégios religiosos femininos e masculinos em Minas gerais: um mapeamento ainda provisório". Educação em Revista. Vol. 8, n. 17, p. 47-55, 1993.

OLIVEIRA, Pedro A. Ribeiro. "Catolicismo popular e romanização do catolicismo brasileiro". Revista Eclesiástica Brasileira. Vol. 36, n. 141, p. 53-81, 1976.

OLIVEIRA, Pedro A Ribeiro de; ARAúJO, Maria das Graças F de. "Pequenos Santos": uma devoção familiar. PLURA: Revista de Estudos de Religião, vol. 2, n. 1, p. 80100, 2011.

PALAZZOLO, Jacinto de. OFM Cap. Nas selvas dos vales do Mucuri e do rio Doce: como surgiu a cidade de Itambacuri, fundada por frei Serafim de Gorizia, missionário capuchinho (1873-1952). $3^{\text {a }}$ ed. São Paulo: Companhia Editora Nacional, 1973.

PEREIRA, Serafim J. OFM Cap. Missionários capuchinhos nas antigas catequeses indígenas e nas sedes do Rio de Janeiro, Espírito Santo e Leste de Minas. Petrópolis: Vozes, 1998.

PORTO, Humberto e SCHLESINGER, Hugo. Dicionário enciclopédico das religiões. Petrópolis: Vozes, 1995. 2 v.

PAULA, João A. de. Raízes da modernidade em Minas Gerais. Belo Horizonte: Autêntica, 2000.

PEREIRA, Serafim J. OFM Cap. Missionários capuchinhos nas antigas catequeses indígenas e nas sedes do Rio de Janeiro, Espírito Santo e Leste de Minas. Petrópolis: Vozes, 1998.

RUBERT, Arlindo. A Igreja no Brasil: expansão territorial e absolutismo estatal (1700-1822). Vol. 3. Santa Maria/RS: Editora Pallotti, 1988.

SALLES, Fritz Teixeira de. Associações religiosas no ciclo do ouro. Belo Horizonte: Universidade de Minas Gerais, 1963.

SANCHIS, Pierre. Arraial: festa de um povo - as romarias portuguesas. Lisboa: Publicações Dom Quixote, 1983.

SANCHIS, Pierre (Org.). Catolicismo: modernidade e tradição. São Paulo: Edições Loyola, 1992. Vol. 1.

Catolicismo: cotidiano e movimentos. São Paulo: Edições Loyola, 1992. Vol. 2.

Catolicismo: unidade religiosa e pluralismo cultural. São Paulo: Edições Loyola, 1992. Vol. 3.

. Fiéis e cidadãos: percursos do sincretismo no Brasil. Rio de Janeiro: EdUERJ, 2001.

SOUZA, João Valdir Alves de. Igreja, educação e práticas culturais: a mediação religiosa no processo de produção/reprodução sociocultural na região do médio Jequitinhonha mineiro. São Paulo: PUC/SP, 2000. 360 p. (Tese, Doutorado em Educação).

SOUZA, João Valdir Alves de; HENRIQUES, Marcio Simeone (Org.). Vale do Jequitinhonha: formação histórica, populações e movimentos. Belo Horizonte: PROEX/UFMG, 2010.

SOUZA, João Valdir Alves de. A festa e o calendário religioso na demarcação dos tempos da vida social. Revista Desenvolvimento Social. Vol. 4, dez. de 2009, Montes Claros/MG, p. 99-111. 
STEIL, Carlos Alberto. "Catolicismo e cultura". In: VALLA, Victor Vincent. (Org.) Religião e cultura popular. Rio de Janeiro: DP\&A, 2001, p. 09-40.

VALLA, Victor Vincent. (Org.) Religião e cultura popular. Rio de Janeiro: DP\&A, 2001.

VEIGA, José Pedro X. da. Efemérides Mineiras: 1664-1897. Belo Horizonte: Fundação João Pinheiro; Centro de Estudos Históricos e Culturais, 1998. 